\title{
PROGRAMME ON ESTABLISHING A SEMI-FREE POPULATION OF PRZEWALSKI'S HORSE IN ORENBURG STATE NATURE RESERVE: THE FIRST SUCCESSFUL PROJECT ON THE REINTRODUCTION OF THE SPECIES IN RUSSIA
}

\author{
Rafilia T. Bakirova*, Tatjana L. Zharkikh \\ Joint Directorate of State Nature Reserves «Orenburg» and «Shaitan-Tau», Russia \\ *e-mail: rbakirova@gmail.com
}

Received: 01.02.2019. Revised: 10.04.2019. Accepted: 15.04.2019.

\begin{abstract}
The Przewalski's horse Equus ferus przewalskii is the only wild representative of the subgenus true horses left in the world. This article discusses the history of projects on the reintroduction of the Przewalski's horse in Russia and compares two different programmes in Orenburg Region given a support from UNDP/GEF Steppe Project. The Programme on restoration of the Przewalski's horse population in Orenburg Region known as the project «Orenburg Tarpania» was developed and managed by the working group comprising representatives from A.N. Severtsov Institute of Ecology and Evolution of RAS, Zoological Museum of Moscow State University, Steppe Institute of Ural Branch of RAS. FSFI «Orenburg Reserves» is the inventor, policymaker, and implementer of the Programme on establishing a semi-free population of the Przewalski's horse in the Orenburg State Nature Reserve supported by the Ministry of Natural Resources and Ecology of the Russian Federation. Despite all interested parties shared the idea to reintroduce Przewalski's horses into the Pre-Urals Steppe site in the Orenburg State Nature Reserve, the Programme by FSFI «Orenburg Reserves» diverges completely from the project «Orenburg Tarpania» on some of the key issues. The main difference between the two projects is the basic goal within the period 20 to 30 years. The project «Orenburg Tarpania» is intended to establish a free population of the Przewalski's horses within its historical area in Russia despite certain risks of economic, financial, social and biological contingencies. The future of the project is uncertain. The Programme on establishing a semi-free population of the Przewalski's horse in the Orenburg State Nature Reserve by FSFI «Orenburg Reserves» has become the first successful attempt to restore wild horses in their nature habitats in Russia. The Programme aims to establish a sustainable breeding population of genetic valuable pure-bred Przewalski's horses in a fenced nature area. FSFI «Orenburg Reserves» has successfully developed and launched the Programme over the past four years: the Reintroduction Centre was built, several groups of founder horses were brought to the Orenburg State Nature Reserve, acclimatised there, some have already been released into the main territory of Pre-Urals Steppe.
\end{abstract}

Key words: Equus ferus przewalskii, Orenburg region, Orenburg Tarpania, UNDP/GEF Steppe Project

\section{Introduction}

The Przewalski's horse Equus ferus przewalskii Poliakov, 1881 is the only wild representative of the subgenus true horses (Equus) left in the world. The history of the species including its discovering, preservation and breeding in captivity is well known (Boyd \& Houpt, 1994). The species become extinct in the wild in late 1960s. Due to effort of zoos, breeding centres, scientific and nature-conservation institutions the population of the Przewalski's horse in captivity grow to the extent that projects on the reintroduction of the species into the wild were developed in 1980s (Przewalski's horse and restoration, 1986). The first most successful projects known as Hustain-Nuruu and Takhin-Tal were launched in Mongolia in 1992.
Totally eleven large breeding and re-introduction centres for the Przewalski's horse including four in Europe and seven in Asia have been established since then (King, 2005; Zharkikh \& Yasynetska, 2005; Zimmermann, 2005; Joly et al., 2014; Liu et al., 2014). This article discusses the history of projects on the reintroduction of the Przewalski's horse in Russia and compares two different programmes in Orenburg Region.

\section{The project on restoration of the Przewalski's horse population in Orenburg Region (Orenburg Tarpania) \\ Some initiatives to establish wild populations of the Przewalski's horse in Russia were con- sidered at the same time as drawing up the first}


Mongolian projects (Klimov, 1986; Sokolov et al., 1990). However, combined with the difficulties related to the collapse of the USSR and lack of sufficient funding of nature conservation initiatives at that time, the development of such reintroduction projects was hindered by the absence of suitable sites for free habitation of such large and mobile ungulates as Przewalski's horses.

It is widely recognised that an essential condition to carry out a reintroduction project is availability of strict protected areas or a nature reserve with a territory which large enough for habitation of a self-sustaining population of a given animal species (IUCN/SSC, 2013).

Until recently, there have not been sizeable steppe Protected Areas in Russia where large populations of Przewalski's horses would inhabit without damage for local ecosystems and they would stay within the Protected Areas.

The initiative to reintroduce the Przewalski's horse to Orenburg Region was first raised in 2002. The Steppe Institute of Ural Branch of RAS proposed the former military range called «Orlov Steppe» of $165 \mathrm{~km}^{2}$ in size as a site suitable for the reintroduction (Chibilev \& Levykin, 2003; Chibilev, 2014). The working group comprising representatives from A.N. Severtsov Institute of Ecology and Evolution of RAS, Zoological Museum of Moscow State University, Steppe Institute of Ural Branch of RAS was set up in 2002. The group developed the Programme on restoration of the Przewalski's horse in Orenburg Region in 2005 (Rozhnov et al., 2010). Later the Programme became widely known as the project «Orenburg Tarpania».

For a long time, this initiative could not have been realized due to a number of factors among which was the lack of a legal entity. The non-profit foundation named «Orenburg Tarpania» had been implementing the Programme since 2007 (Levykin \& Kazachkov, 2009). So, the Programme later has been referred to as «Orenburg Tarpania» since then. The foundation supposed to rent the Orlov Steppe site and then began managing the area to preserve steppe ecosystems and to reintroduce the Przewalski's horse there (Chibilev, 2015).

In 2007 and 2008, the initiative was considered by some European (German) conservation organizations including Zoological Society for the Conservation of Species and Population, Conservation Breeding Programme for the A-Line Przewalski's Horse, European Endangered Spe- cies Programme for the Przewalski's Horse (Minutes of the Workshop, 2009). Yet, the detailed management plan of «Orenburg Tarpania» was not developed (Levykin \& Kazachkov, 2009), so, the potential foreign partners neither contributed funds nor advocated the project.

In 2010, the Project 00072294 «Improving the Coverage and Management Efficiency of Protected Areas in the Steppe Biome of Russia» by The United Nations Development Programme / Global Environment Facility known as UNDP/GEF Steppe Project provided support to «Orenburg Tarpania» as it was considered a model of a protected nature steppe area managing by a non-commercial organization (Smelyanskiy, 2010; Stepanitskij, 2011). The Project provided funding for the development of a working project for the reintroduction of the Przewalski's horse and for a business-plan of the investment project to sustain the development of the tourism in the Special Steppe Administered Territory «Orenburg Tarpania».

With the support of the Orenburg Regional Government and with funding from non-bank private investors the Breeding Centre for Steppe Animals (BCSA) with a local zoo as a part of «Orenburg Tarpania» was built in the village of Sazan, Orenburg Region, in 2013. The zoo was designed to keep and breed Przewalski's horses, kiangs (Equus kiang Moorcroft, 1841), kulans (Equus hemionus kulan Groves et Mazák, 1967), yaks (Bos grunniens Linnaeus, 1766), Bactrian camels (Camelus bactrianus Linnaeus, 1758), saigas (Saiga tatarica Linnaeus, 1758), bisons (Bison bison bison Linnaeus, 1758), as well as some rare breeds of domestic horses like Yakut and Bashkir horses (Chibilev et al., 2015). One more enclosure of wire mesh was planned to be constructed a few kilometres from the village on community-owned land for the haymaking; this gave rise to protests by local communities. After acclimatization animals intended for reintroduction should have been driven through temporary corridors from the zoo enclosures to enclosures of electric fence in the territory of the Reserve (N. Spasskaya, personal communication).

However, the project «Orenburg Tarpania» had been no further developments given the lack of sufficient and assured funding. The attempt of UNDP/GEF Steppe Project to encourage establishing a non-government protected nature area owned and administered by the non-commercial organization was considered failures (Smelyanskiy, 2017). 
The first Przewalski's horses were brought to BCSA in 2014 (Levykin \& Kazachkov, 2017). Out of all imported horses only a female from Moscow Zoo is registered in the General Studbook. Other specimens have unknown parentage. Horses from Orel Region originate in a population which has got specimens with white stars on forehead and hanging manes. A male from Rostov is a descendant of a specimen carried the fox-gene. Some demographic parameters are showed in Table 1. Several hybrids by a Przewalski's stallion out of domestic mares owned by local people were born in the village of Sazan in 2015 and 2016. There were four Przewalski's horses (Equus ferus przewalskii), three kiangs (Equus kiang), small groups of yaks (Bos grunniens), camels (Camelus bactrianus) and domestic goats (Capra aegagrus hircus Linnaeus, 1758) in BCSA in March, 2019.

\section{Programme on establishing a semi-free population of the Przewalski's horse in the Orenburg State Nature Reserve}

The Orenburg State Nature Reserve (hereinafter Orenburg Reserve) became directly involved in works on the reintroduction in 2013. The Reserve has become a part of Federal State Funded Institution Joint Directorate of State Nature Reserves «Orenburg» and «Shaitan-Tau» (hereinafter FSFI «Orenburg Reserves») since autumn 2014. The international experience on maintenance of the Przewalski's horse in captivity and restoration to its natural habitats was fully investigated. Ecological conditions and socio-economic settings of the area of alleged reintroduction, the costs of the implement the initial stage including transporting of founder horses of the population, funding sources for guard and monitoring of free-roaming Przewalski's horses were assessed.

All interested parties including UNDP/GEF Steppe Project, the Ministry of Natural Resources and Ecology of the Russian Federation, «Orenburg Tarpania», Orenburg Reserve agreed that a project on the reintroduction should be launched in a territory under strict Protected Area status on the federal level. UNDP/GEF Steppe Project provided funds to the Steppe Institute of Ural Branch of RAS for the development of the ecological and economic justification for the expansion of Orenburg Reserve area (Chibilev et al., 2013). In 2015, the former military range "Orlov Steppe» of 165.38 $\mathrm{km}^{2}$ was transferred into Orenburg State Nature Reserve ownership (Government of the Russian Federation Decree 700 of 13 July 2015). The new site of Orenburg Reserve named «PreUrals Steppe» was situated in the Belyaevka district and Akbulak disctrict of Orenburg Region, $120 \mathrm{~km}$ outside the Orenburg. The centre of the site is located at $51.1826 \mathrm{~N}, 56.1817 \mathrm{E}$.

A comprehensive analysis of conditions of Pre-Urals Steppe and around territories as well as specific features of Orenburg Reserve functioning under environmental legislation revealed that the project «Orenburg Tarpania» could not be implemented in the Pre-Urals Steppe site. In particular, the initiators of the project made a decision to place their Breeding Centre for Steppe Animals outside the territory of the future strict Protected Area, to the village of Sazan. Orenburg Reserve developed internally the Programme on establishing a semi-free population of the Przewalski's horse in the Orenburg State Nature Reserve in 2014-2015.

Table 1. Demographic parameters of the group of Przewalski's horses in the zoo of the project «Orenburg Tarpania»

\begin{tabular}{|l|c|c|c|c|c|}
\hline \multicolumn{1}{|c|}{ Place of birth } & Sex & Date of birth & Date of transfer & Date of death & Cause of death \\
\hline Moscow Zoo & female & 2012 & 2014 & - & - \\
\hline $\begin{array}{l}\text { Orel Region, } \\
\text { private zoo }\end{array}$ & female & unknown & 2014 & October 2015 & $\begin{array}{l}\text { the pregnant female died as a result of injuries } \\
\text { incurred during attempts to take her blood for } \\
\text { scientific investigations without medical im- } \\
\text { mobilization }\end{array}$ \\
\hline $\begin{array}{l}\text { Orel Region, } \\
\text { private zoo }\end{array}$ & male & unknown & 2014 & July 2016 & $\begin{array}{l}\text { the male was killed unintentionally while being } \\
\text { captured with a rope for veterinary treatment }\end{array}$ \\
\hline Rostov-Don Zoo & male & 2012 & 2018 & - & - \\
\hline Orenburg Tarpania & $?$ & 2015 & - & 2015 & $\begin{array}{l}\text { the foal died a day after birth, its sex and cause } \\
\text { of death were not reported }\end{array}$ \\
\hline Orenburg Tarpania & female & 2016 & - & - & - \\
\hline Orenburg Tarpania & male & 2017 & - & - & - \\
\hline
\end{tabular}


The decision to establish a semi-free population was made in view of the experience of other projects on the Przewalski's horse reintroduction. In Mongolia, some young Przewalski's males were watched outside the Hustai National Park of 500 $\mathrm{km}^{2}$ in size in four years after the first groups of reintroduced horses had been released from their acclimatization enclosures (Bouman, 1998). In Chernobyl Exclusive Zone of $2600 \mathrm{~km}^{2}$, home ranges of two harems of Przewalski's horses totalled about $330 \mathrm{~km}^{2}$ in three years after their release (Zharkikh et al., 2002). Some Przewalski's horses left the territory of Ukrainian part of Chernobyl Exclusive Zone in eight years after their release (Zharkikh \& Yasynetska, 2009). It proves that the minimum size of an area for the long-term existence of a sustainable free-roaming population of Przewalski's horses should exceed several hundred square kilometres whereas Pre-Urals Steppe is much less in size.

Horse herding is well-developed in rural areas of Orenburg Region. Herds of domestic horses numbering several to hundred specimens roam free around each small settlement including villages near Pre-Urals Steppe. Certainly, after release from acclimatization enclosures Przewalski's horses would have soon left the unfenced Protected Area and began bothering herds of domestic horses, damaging crops. This would have invited complaints from local people. Moreover, the PreUrals Steppe site is situated $17 \mathrm{~km}$ from Kazakhstan border and horse stealing sometime occurs in this area. Accordingly, there would have been imminent risks of both hybridization and poaching.

That is why Orenburg Reserve did not favour the idea on establishing a free-roaming population of the Przewalski's horse. According to the law, rangers of state nature reserves have rights to guard only strict protected areas and their protective zones. But, even if theoretically the special staff would have been employed 1) financing of protection and monitoring of wild animals outside Protected Areas had been unreasonably and 2) no any method to influence movements of wild horses had existed.

Taking into account the above-mentioned reasons the Ministry of Natural Resources and Ecology of the Russian Federation supported the proposal of Orenburg Reserve to establish a semi-free population of the Przewalski's horse which would be guaranteed to be protected against hybridization and poaching. The Ministry funded the building of the fence around the whole territory of Pre-Urals Steppe. The site with perimeter of $52 \mathrm{~km}$ was fenced with wire mesh «Tornado» fixed to metal poles $2 \mathrm{~m}$ in high in September 2016. The mesh size is irregular with $300 \times 300 \mathrm{~mm}$ in the top and bottom parts and $300 \times 50 \mathrm{~mm}$ in the middle strengthened part. Any local wild steppe animals may easily move inside and outside the fenced site through the mesh.

In 2014, Orenburg Reserve conducted expert assessments of sites proposed for construction of acclimatization enclosures in Pre-Urals Steppe. The locations recommended by specialists of «Orenburg Tarpania» were not optimal in transport accessibility, the construction cost, forage capacity. Thus, another location was chosen to build the Reintroduction Centre of Orenburg Reserve (Zharkikh \& Linerova, 2016).

A realistic action plan for the first stage of the Programme, helped in short terms to attract sufficient funding for infrastructure preparation and transporting of founder horses from both UNDP/GEF Steppe Project (Williams, 2016) and the federal budget.

In 2015, the Reintroduction Centre for the Przewalski's horse was constructed in Pre-Urals Steppe. Planning decisions for the Centre were entirely different from any other projects (Bakirova \& Zharkikh, 2015). Two permanent acclimatization enclosures were constructed of wire mesh fixed to metal poles. Two lines of electric fence on either side of the metal mesh prevent horses from contacts with mesh (an electric fence alone cannot reliable keep wild horses inside). The imported Przewalski's horses were kept in the enclosures for about a year. After they had been released outside the next group of horses transported and placed into the enclosure. This resulted in savings of funds and efforts for acclimatization of imported animals.

FSFI «Orenburg Reserves» is the implementer of the Programme on establishing a semi-free population of the Przewalski's horse in Orenburg State Nature Reserve supported by the Ministry of Natural Resources and Ecology of the Russian Federation. From a juridical standpoint, legitimacy of the Programme was given during the process of the expansion of the protected area and after FSFI «Orenburg Reserves» had been designated as the implementing agency for special measures on preservation of rare species: more specifically, for establishing a new breeding centre for the Przewalski's horse (Order of the Ministry of Natural Resources and Ecology of the Russian Federation № 33-p of 01.12.2014).

As there are almost no Przewalski's horses valuable in terms of genetics in Russian zoos, FSFI «Orenburg Reserves» has made a deal with ones of the best semi-reserved sites in Europe to bring for the Programme pure-bred Przewalski's horses adapted to wild nature habitats. There were 
six specimens from Association pour le Cheval de Przewalski: TAKH (France) transported to Orenburg Reserve in 2015. And 30 specimens from Hortobágy Nemzeti Park (Hungary) were transported to Orenburg Reserve in 2016 and 2017.

FSFI «Orenburg Reserves» regularly provides information about its Przewalski's horses to the keeper of the General Studbook (Prague Zoo) and pursues contacts with the European Endangered Species Programme for the Przewalski's Horse (Cologne Zoo).

The Ministry of Natural Resources and Ecology of the Russian Federation has approved the Perspective Plan of Research Work for the Pre-Urals Steppe site of Orenburg Reserve for the medium term. Besides investigations of the Przewalski's horse, the Plan includes studies of the dynamics of nature complexes and their components in the site. Therefore, the Directorate of FSFI «Orenburg Reserves» and its departments lead any projects and research in the territories of Orenburg Reserve. Safeguarding the territory and animals, monitoring and scientific researchers are financed from the federal budget and guaranteed by the State according to existing legislation.

Research in Pre-Urals Steppe undertaken since 2015 have branched into several specific topics to improve the management plan for the Przewalski's horse population. The staff members of the Reintroduction Centre routinely collect data on demography, basic ethological parameters, distribution over the area, social behaviour and some others. A pilot study of vegetation around the Reintroduction Centre was completed in 2015 (Zharkikh \& Linerova, 2016). The next year a vegetation map of the whole area and a study of productivity of different plant communities were carried out in cooperation with Ufa Institute of Biology of Ufa Research Centre of RAS and Botanical Garden-Institute of Ufa Research Centre of RAS (Fedorov et al., 2018, 2019; Golovanov et al., 2018). At present, some GIS-technologies (remote sensing) are used to study the dynamics of vegetation productivity depending on climatic changes. The study of the influence of Przewalski's horse grazing on grass productivity in this area continues. Investigations of the species composition of the intestinal parasite community in Przewalski's horses have been carried out in cooperation with the Falz-Fein Biosphere Reserve «Askania Nova» and Kyev Institute of Zoology, Ukraine (Kuzmina et al., 2017), Orenburg Agrarian University, Russia. The dynamics of the parasite infection are monitored. Some ethological studies are conducted in cooperation with the Samara State University, Russia and Warsaw University of Life Sciences, Poland. Also, researchers of the FSFI «Orenburg Reserves» study insects and small mammals of the area.

\section{Comparative characteristics of these two projects}

Despite all interested parties shared the idea to reintroduce Przewalski's horses into Pre-Urals Steppe, the Programme by FSFI «Orenburg Reserves» diverges completely from the project «Orenburg Tarpania» on some of the key issues (Table 2).

Table 2. Comparative characteristics of two projects on reintroduction of the Przewalski's horse

\begin{tabular}{|c|c|}
\hline Programme by FSFI «Orenburg Reserves» & Project «Orenburg Tarpania» \\
\hline \multicolumn{2}{|l|}{ Scientific administration: } \\
\hline FSFI «Orenburg Reserves» & $\begin{array}{l}\text { External administration by Steppe Institute of UB RAS, A.N. Severt- } \\
\text { sov Institute of Ecology and Evolution RAS, Zoological Museum of } \\
\text { Moscow State University }\end{array}$ \\
\hline \multicolumn{2}{|l|}{ Goal: } \\
\hline $\begin{array}{l}\text { Establishing a semi-free population of the Przewalski's horse in the } \\
\text { fenced strict protected area }\end{array}$ & $\begin{array}{l}\text { Establishing some free populations of the Przewalski's horse and } \\
\text { other ungulates in Orenburg Region }\end{array}$ \\
\hline \multicolumn{2}{|l|}{ Financing: } \\
\hline guaranteed by the State & private investment and donations \\
\hline \multicolumn{2}{|l|}{ Constructing infrastructure for the Reintroduction Centre: } \\
\hline within the strict protected area & outside the strict protected area in lands rented by private investors \\
\hline \multicolumn{2}{|l|}{ Selection of location for acclimatization enclosures: } \\
\hline $\begin{array}{l}\text { A pilot research of vegetation to evaluate its productivity and fod- } \\
\text { der stocks in this area was fulfilled }\end{array}$ & Botanical investigations were not conducted \\
\hline \multicolumn{2}{|l|}{ Founders of the new population: } \\
\hline $\begin{array}{l}\text { The Przewalski's horses must be registered in the General Stud- } \\
\text { book and recommended to be bred by EEP and/or other relevant } \\
\text { institutions }\end{array}$ & $\begin{array}{l}\text { Przewalski's horses of unknown origin, not registered in the General } \\
\text { Studbook and/or excluded from breeding by EEP }\end{array}$ \\
\hline \multicolumn{2}{|c|}{ Routine veterinary, zoo-technical practices and monitoring are carried out by } \\
\hline specialists of Orenburg Reserve & resource persons from Moscow and Orenburg research institutes \\
\hline \multicolumn{2}{|l|}{ Collaboration with EEP for the Przewalski's horse: } \\
\hline Necessary & Not necessary \\
\hline
\end{tabular}




\section{Conclusions}

The main difference between the two projects is the basic goal within the period 20 to 30 years. The project «Orenburg Tarpania» is intended to establish a free population of the Przewalski's horse within its historical area in Russia (Rozhnov et al., 2010) despite certain risks of economic, financial, social and biological contingencies. The future of the project is still uncertain.

Although the Programme on establishing a semi-free population of the Przewalski's horse in Orenburg State Nature Reserve was elaborated in a relatively short terms, it meets the main principles set out in the IUCN/SSC Guidelines for reintroductions and other conservation translocations (IUCN/SSC, 2013).

The Programme on establishing a semi-free population of the Przewalski's horse in Orenburg State Nature Reserve by FSFI «Orenburg Reserves» has become the first successful attempt to restore wild horses in their nature habitats in Russia. The Programme aims to establish a sustainable breeding population of genetic valuable pure-bred Przewalski's horses in a fenced nature area. FSFI «Orenburg Reserves» has successfully developed and launched the Programme over the past four years: the Reintroduction Centre was built, several groups of founder horses were brought to Orenburg Reserve, acclimatized there, some were released into the main territory of Pre-Urals Steppe.

\section{References}

Bakirova R.T., Zharkikh T.L. 2015. The first stage of the reintroduction of the Przewalski's horse at the Orenburg Reserve. The preparation of infrastructure. Steppe Bulletin 45: 62-64. [In Russian]

Bouman I. 1998. The reintroduction of Przewalski's horses in the Hustain Nuruu Mountain Forest Steppe Reserve in Mongolia. Nederlandsche Commissie voor Internationale Natuurbescherming. Mededelingen. Vol. 32. 50 p.

Boyd L., Houpt K.A. (Eds). 1994. Przewalski's Horse: the History and Biology of an Endangered Species. New York: State University of New York Press. 313 p.

Chibilev A.A. 2014. Orenburg Reserve: the background to the establishment and its natural diversity. Ekaterinburg: UIPTs. 137 p. [In Russian]

Chibilev A.A. 2015. A remark of the principal investigator of the project «Orenburg Tarpania». Steppe Bulletin 45: 65-66. [In Russian]

Chibilev A.A., Levykin S.V. 2003. Regional specificities of current land use in Orenburg Region. In: Proceedings of the International Conference "Interaction between community and environment under conditions of global and regional developments». Barnaul - Moscow. P. 383-384. [In Russian]

Chibilev A.A., Levykin S.V., Velmovskij P.V. 2013. Development of the ecological and economic justification and a package of documents for the expansion of territory of Orenburg State Nature Reserve through the organization a new protected site «Orlov Steppe». The report on research work of The Steppe Institute of Ural Branch of RAS, 2013. 253 p. [In Russian]

Chibilev A.A., Sokolov A.A., Rudneva O.S. 2015. Orenburg region tourist guide: the unique routs. Orenburg: Orenburg Branch of the Russian Geographical Society, the Steppe Institute UB RAS. 70 p. [In Russian]

Fedorov N.I., Mikhailenko O.I., Zharkikh T.L., Bakirova R.T. 2018. Mapping of Vegetation with the Geoinformation System and Determining of Carrying Capacity of the Pre-Urals Steppe area for a Newly Establishing Population of the Przewalski Horse Equus ferus przewalskii at the Orenburg State Nature Reserve. IOP Conference Series: Earth and Environmental Science 107(1): 012100. DOI: 10.1088/1755-1315/107/1/012100

Fedorov N.I., Zharkikh T.L., Mikhailenko O.I., Bakirova R.T. 2019. The Use of NDVI for the Analysis of the Effect of Drought on Vegetation Productivity in the Pre-Urals Steppe Area Where a Population of the Przewalski Horse Equus Ferus Przewalskii Polj., 1881 Had Been Established. In: I. Bychkov, V. Voronin (Eds.): Information Technologies in the Research of Biodiversity. Cham: Springer. P. 1-7. DOI:10.1007/978-3-030-11720-7_1

Golovanov Ya.M., Yamalov S.M., Lebedeva M.V., Bakirova R.T., Zharkikh T.L. 2018. Flora of Pre-Urals Steppe of Orenburg Reserve (Orenburg Region, Russian Federation). Bulletin of Bryansk dpt. of RBS 1(13): 10-21. [In Russian]

IUCN/SSC. 2013. Guidelines for Reintroductions and Other Conservation Translocations. Version 1.0. Gland, Switzerland: IUCN Species Survival Commission. 57 p.

Joly F., Mesléard F., Feh C. 2014. La réintroduction du Cheval de Przewalski's en Mongolie: la population de Khomyn Tal - zone tampon du Parc National de Khar Us nuur. In: M. Gauthier-Clerc, F. Mesléard, J. Blondel (Eds.): Sciences de la conservation. De Boeck: Louvain-la-Neuve. P. 25-28.

King S.R.B. 2005. Extinct in the wild to Endangered: the history of Przewalski's Horse (Equus ferus przewalskii) and its future conservation. Mongolian Journal of Biological Sciences 3(2): 37-41.

Klimov V. 1986. Przewalski's horse gene pool preservation methods. In: The Przewalski's horse and restoration to its natural habitat in Mongolia. FAO/UNEP Expert Consultation held in Moscow USSR (29-31 May, 1985). Rome: Food and Agriculture Organization of the United Nations. FAO Animal Production and Health Paper 61.

Kuzmina T.A., Zvegintsova N.S., Zharkikh T.L. 2017. Gastrointestinal parasite community in a new population of 
the Przewalski's horse (Equus ferus przewalskii) in the Orenburg State Reserve, Russia. Vestnik Zoologii 51(3): 243-250. DOI: 10.1515/vzoo-2017-0030

Levykin S.V., Kazachkov G.V. 2009. Orlov Steppe: a testing ground for new methods of protection and restoration of steppes. Steppe Bulletin 26: 23-26. [In Russian]

Levykin S.V., Kazachkov G.V. 2017. Orenburgskaya Tarpania as the key element of steppe social and ecological rehabilitation. Socio-Environmental Technologies 3: 9-23. [In Russian]

Liu G., Shafer A.B.A., Zimmermann W., Hu D., Wang W., Chu H., Cao J., Zhao C. 2014. Evaluating the reintroduction project of Przewalski's horse in China using genetic and pedigree data. Biological Conservation 171: 288-298. DOI: 10.1016/j.biocon.2013.11.022

Minutes of the Workshop on the A-line Przewalski's horse (Munich Zoo Hellabrunn, 18 May, 2009). Hellabrunn, 2009.

Przewalski's horse and restoration to its natural habitat in Mongolia. FAO/UNEP Expert Consultation held in Moscow USSR, (Moscow, 29-31 May 1985). Rome: Food and Agriculture Organization of the United Nations, 1986. 188 p. FAO Animal Production and Health Paper 61.

Rozhnov V.V., Spasskaya N.N., Chibilev A.A., Levykin S.V., Orlov V.N., Paklina N.V., Pozdnyakova M.K., Petrishev B.I. 2010. Programme on restoration of the Przewalski's horse in Orenburg Region, 2010. Moscow: KMK Scientific Press Ltd. 32 p. [In Russian]

Smelyanskiy I. 2010. Global Environment Facility has supported the preservation of steppe ecosystems in Russia, 2010. Steppe Bulletin 28: 22-23. [In Russian]

Smelyanskiy I. 2017. Russian Steppe Project has been completed: what was done, 2017. Steppe Bulletin 49: 4-13. [In Russian]
Sokolov V.E., Orlov V.N., Severtsov A.N. 1990. Prospects of reintroduction of the Przewalski's horse into the wild. In: V International Symposium on the Preservation of the Przewalski's horse. Leipzig: Zool. Garten Leipzig. P. 202-204.

Stepanitskij V.B. (Ed.). 2011. Work Plan for the Project for the period May 2010 to May 2015. In: UNDP/GEF Project 00072294 "Improving the Coverage and Management Efficiency of Protected Areas in the Steppe Biome of Russia». National Director of the Project on 30 March, 2011. [In Russian]

Williams S. 2016. Improving the coverage and management efficiency of protected areas in the Steppe Biome of Russia. PIMS 4194, Atlas project number 00072294. Terminal Evaluation, December 2016. Vol. 1. 77 p.

Zharkikh T.L., Linerova L.G. 2016. Evaluation of the fodder stocks for the Przewalski horse Equus ferus przewalskii on the «Pre-Ural steppe» plot of the Orenburg State Nature Reserve. Nature Conservation Research 1(3): 90-94. DOI: 10.24189/ncr.2016.033

Zharkikh T.L., Yasynetska N.I. 2005. A review of some projects of re-introduction of the Przewalski's horse (Equus przewalskii) and recommendations on development of new populations. In: Ungulates in Zoos and Breeding Centres: Inter-department scientific and methodic articles. Moscow: Moscow Zoo. P. 33-60. [In Russian]

Zharkikh T.L., Yasynetska N.I. 2009. Ten years of development of the Przewalski's horse population in the Chernobyl Excusive Zone. Equus. P. 139-156.

Zharkikh T.L., Yasynetska N.I., Zvegintsova N.S. 2002. Przewalski's horse in the Zone of Chernobyl nuclear power. Gazella 29: 93-111.

Zimmermann W. 2005. Przewalskipferde auf dem Weg zur Wiedereinbürgerung - Verschiedene Projekte im Vergleich. Zeitschrift des Kölner Zoo 4: 183-209. 


\title{
ПРОГРАММА СОЗДАНИЯ ПОЛУВОЛЬНОЙ ПОПУЛЯЦИИ ЛОШАДИ ПРЖЕВАЛЬСКОГО В ОРЕНБУРГСКОМ ЗАПОВЕДНИКЕ: ПЕРВЫЙ УСПЕШНЫЙ ПРОЕКТ РЕИНТРОДУКЦИИ ВИДА В РОССИИ
}

\author{
Р. Т. Бакирова*, Т. Л. Жарких
}

Объединенная дирекиия государственных природных заповедников «Оренбургский» и «Шайтан-Тау», Россия *e-mail: rbakirova@gmail.com

\begin{abstract}
Лошадь Пржевальского Equus ferus przewalskii - единственный дикий представитель подрода настоящих лошадей (Equus), сохранившийся до наших дней. В статье обсуждается история проектов по реинтродукции лошади Пржевальского в России и сравниваются две разные программы в Оренбургской области, получившие поддержку Степного проекта ПРООН/ГЭФ. Программа по восстановлению лошади Пржевальского в Оренбургской области, известная как проект «Оренбургская Тарпания», была разработана и ведётся рабочей группой, состоящей из представителей Института проблем экологии и эволюции имени Северцова РАН, Зоологического музея МГУ, Степного института Уральского отделения РАН. ФГБУ «Заповедники Оренбуржья» является разработчиком и исполнителем Программы создания полувольной популяции лошади Пржевальского в Государственном природном заповеднике «Оренбургский» при поддержке Министерства природных ресурсов и экологии Российской Федерации. Несмотря на то, что все заинтересованные стороны поддержали идею реинтродукции лошадей Пржевальского на участке Предуральская степь Оренбургского заповедника, программа ФГБУ «Заповедники Оренбуржья» полностью отличается от проекта «Оренбургская Тарпания» по ряду ключевых позиций. Основное различие между этими двумя проектами - их основная цель на период от 20 до 30 лет. Проект «Оренбургская Тарпания» нацелен на создание вольных популяций лошади Пржевальского в пределах её исторического ареала в России, несмотря на определённые экономическо-финансовые, социальные и биологические риски. Будущее этого проекта неясно. Программа создания полувольной популяции лошади Пржевальского в Оренбургском заповеднике, разработанная и воплощаемая ФГБУ «Заповедники Оренбуржья», стала первой успешной попыткой восстановления диких лошадей в их естественной среде обитания в России. Программа направлена на создание устойчивой размножающейся популяции генетически ценных чистокровных лошадей Пржевальского на огороженном участке ООПТ. За последние четыре года ФГБУ «Заповедники Оренбуржья» успешно выполнила первый этап Программы: построен Центр реинтродукции, в Оренбургский заповедник были привезены и акклиматизированы несколько групп животных-основателей, некоторые уже выпущены на основную территорию участка Предуральская степь.
\end{abstract}

Ключевые слова: Equus ferus przewalskii, Заповедники Оренбуржья, Оренбургская область, Оренбургская Тарпания, степной проект ПРООН/ГЭФ 